\title{
Androgen receptor CAG polymorphism (Xq11-12) status and human spermatogenesis: A prospective analysis of infertile males and their offspring conceived by intracytoplasmic sperm injection
}

\author{
YUKIKO KATAGIRI ${ }^{1}$, QUEENIE V. NERI ${ }^{1}$, TAKUMI TAKEUCHI ${ }^{1}$, FRED MOY $^{2}$, \\ ERIC SCOTT SILLS ${ }^{3}$ and GIANPIERO D. PALERMO ${ }^{1}$
}

\author{
${ }^{1}$ The Center for Reproductive Medicine and Infertility, Weill Medical College of Cornell University, NY; \\ ${ }^{2}$ Department of Statistics, Graduate School of Basic Medical Science, New York Medical College, \\ Valhalla, NY; ${ }^{3}$ Department of Obstetrics, Gynecology and Reproductive Research, \\ Murphy Medical Center, Murphy, NC, USA
}

Received February 14, 2006; Accepted April 10, 2006

\begin{abstract}
We determined the association of androgen receptor (AR) $(\mathrm{CAG})_{\mathrm{n}}$ lengths among fertile and infertile males and offspring conceived by intracytoplasmic sperm injection (ICSI). Assessment of (CAG) $)_{n}$ repeats in the AR was performed in a Caucasian population by gene sequencing in fertile men $(n=13)$, infertile men $(n=64)$, boys conceived after ICSI $(n=21)$, and boys conceived naturally $(n=11)$. In the AZF region of the Y chromosome, a total of 22 STSs were analyzed by multiplex PCR; selected spermatozoa were also analyzed by fluorescent in situ hybridization (FISH) for chromosomes $18,21, \mathrm{X}$, and $\mathrm{Y}$. The average age was $43.7 \pm 7 \mathrm{yr}$ for infertile, $44.8 \pm 7 \mathrm{yr}$ for fertile men, and $5.0 \pm 0.5 \mathrm{yr}$ for the children. The mean $(\mathrm{CAG})_{\mathrm{n}}$ was $22.2 \pm 3$ for the infertile men and $19.3 \pm 5$ for fertile controls. There was a significant difference in CAG repeat length in the severely oligo-/azoo-spermic men vs. controls $(\mathrm{p}=0.02)$. An inverse correlation was evident between CAG length and semen parameters. For ICSI male children, the AR $(\mathrm{CAG})_{\mathrm{n}}$ lengths were $21.4 \pm 3.2$ vs. $20.8 \pm 3.4$ for boys conceived naturally. While all peripheral karyotypes of fertile and infertile men were normal, de novo gonosomal abnormalities were observed in the ICSI offspring. The incidence of $\mathrm{Y}$ microdeletions was $1.6 \%$ in infertile men; all the ICSI sons had an intact $\mathrm{Y}$ chromosome. In conclusion, severely oligoand azoospermic men had longer CAG repeat length than fertile controls, suggesting that certain AR gene mutations may have a negative effect on spermatogenesis. An increased
\end{abstract}

Correspondence to: Dr G.D. Palermo, Weill Medical College of Cornell University, 505 East 70th Street, HT-336, New York, NY 10021, USA

E-mail: gdpalerm@med.cornell.edu

Key words: androgen receptor gene, trinucleotide polymorphism, intracytoplasmic sperm injection incidence of de novo gonosomal abnormalities was found in the ICSI offspring when compared to children conceived naturally. Our assessment of the polymorphic region of the AR gene, in the absence of other specific genomic abnormalities, suggests that the fertility of children conceived by ICSI may be conserved.

\section{Introduction}

Intracytoplasmic sperm injection (ICSI) potentiates successful treatment of infertile couples with in vitro fertilization where the male partner has compromised sperm parameters $(1,2)$. Many of these infertile men have impaired spermatogenesis and often exhibit related genetic disorders including chromosomal aneuploidy, structural chromosomal rearrangements, or mutations/deletions that are assessable only at the molecular level (3). Even when chromosomal defects are not observed in the peripheral karyotype, in spermatozoon these are about twice as common as in normal donor semen (4,5). For example, single gene mutations such as those on chromosome 7 and deletions in the Yq AZF may be present in men with obstructive azoospermia and carriers of the cystic fibrosis trait $(6,7)$.

Both spermatogenesis and normal male sexual development are under the control of the androgen receptor (AR) gene, located on the long arm of the $\mathrm{X}$ chromosome at Xq11-12 (8). The AR gene has 8 exons that encode 3 protein domains. A polymorphic CAG (glutamine) repeat sequence is in exon 1 . The AR-CAG repeat region is unstable and its length may sometimes undergo expansion or contraction during meiotic DNA replication. Mutations in this gene have been associated with various disorders including complete androgen insensitivity syndrome (9), various motor neuron diseases, and prostate and ovarian cancers (10). The length of CAG repeats influences AR function; enhanced androgen action is associated with fewer repeat lengths and decreased AR function occurs with longer CAG repeat lengths. Interestingly, the AR also plays an important role in the nervous system. Males with Kennedy's disease (a serious 
neurodegenerative disorder) exhibit over 40 CAG repeats in the AR gene and show compromised spermatogenesis and subsequent infertility (11). Normally, CAG repeat length is between 9 and 36 (12) although an even narrower range (8 to 27$)$ has been detected in some fertile men $(13,14)$. The length of these $(\mathrm{CAG})_{\mathrm{n}}$ has also been noted to vary by ethnicity, with an average of 21 repeats in Caucasian men, 18 in African-Americans, and 22 in Asian men (15).

This study investigated the relationship between fluctuations in the trinucleotide repeat (TNR) region and semen characteristics of Caucasian infertile men treated by ICSI. A group matched for age and ethnicity was used as a control. We also assessed the CAG repeat length in male children conceived by ICSI and compared them to boys from natural conception. To identify any other factors affecting spermatogenesis, we conducted additional genetic tests for male infertility such as Yq microdeletion and chromosomal analysis of spermatozoa. Against this background, the study aimed to screen infertile men and their children for any relationship between spermatogenesis and their genomic profile. We also investigated whether sequencing of the AR gene may predict subsequent spermatogenesis in ICSI offspring.

\section{Materials and methods}

Patients. Following institutional review board approval (IRB \#0299-581), a total of 64 Caucasian males with abnormal sperm parameters and 21 ICSI sons provided blood samples for genetic characterization. Control subjects consisted of 13 fertile males matched for age and ethnicity as well as 11 boys conceived without medical assistance.

Specimen classification. For this investigation, semen parameters were considered normal when a concentration of $\geq 20 \times 10^{6} / \mathrm{ml}$, a progressive motility of $\geq 40 \%$, and a normal morphology of $\geq 4 \%$ were confirmed. Sperm concentrations were stratified as follows: mild oligospermia $(\geq 5$ to $<20 \times 10^{6} / \mathrm{ml}$ ), moderate oligospermia ( 1 to $<5 \times 10^{6} / \mathrm{ml}$ ), severe oligospermia $\left(<1 \times 10^{6} / \mathrm{ml}\right)$, or azoospermia (zero spermatozoa).

Extraction of genomic DNA. DNA was purified from peripheral leukocytes with the Wizard Genomic DNA purification kit (Promega, Madison, WI, USA), as previously described (16). DNA content was quantified by optical density determination; DNA concentration/quality were also estimated in relation to control high molecular weight DNA processed by $1 \%$ agarose gel electrophoresis.

PCR amplification. The paired primer sequences flanking exon 1 of the AR gene motif were based on the sequence deposited in the Genebank database (accession \#M35844) (Table I) (17). DNA was amplified using these primers to generate fragments of the N-terminal domain of the AR gene (279 bp). Polymerase chain reaction (PCR) amplification was performed in a final volume of $25 \mu 1$ containing approximately $100 \mathrm{ng}$ of DNA template, $10 \mathrm{mM}$ trishydroxymethylaminomethane (tris) buffer $\mathrm{pH} 8.3,50 \mathrm{mM} \mathrm{KCl}, 2.5$ units of Taq polymerase (Boehringer Mannheim $\mathrm{GmbH}$, Mannheim, Germany), $250 \mu \mathrm{M}$ deoxynucleoside triphosphates, $1.5 \mathrm{mM}$
$\mathrm{Mg}^{++}, 5 \mu 1$ solution Q (Qiagen, Chatsworth, CA, USA), and a primer concentration of $200 \mathrm{nM}$. The thermal cycling profile on a Perkin Elmer 9600 instrument consisted of a $30 \mathrm{sec}$ denaturation step at $95^{\circ} \mathrm{C}$ and a $60 \mathrm{sec}$ extension step at a temperature of $72^{\circ} \mathrm{C}$, for a total of 35 cycles. Each PCR cycle was initiated with a 5 min denaturation step at $95^{\circ} \mathrm{C}$ and terminated with a 5 min extension step at $72^{\circ} \mathrm{C}$. PCR efficiency was verified by running an $8 \mu \mathrm{l}$ aliquot of the PCR product on a $1 \%$ agarose gel containing ethidium bromide (18).

Biallelic analysis was performed for the few cases where two X chromosomes were present. For these samples, fluorescent PCR was performed where the forward (sense) primer was labeled with 6-carboxyfluorescein (6fam) and amplified in 35 cycles (Table I).

DNA sequencing of AR gene. PCR product was purified by the QIAquick PCR purification kit (Qiagen). DNA sequencing reactions were assembled with ABI PRISM ${ }^{\circledR}$ BigDye $^{\text {TM }}$ Terminators V3.1 cycle sequencing kit (Applied Biosystems, Foster City, CA, USA). Reactions were thermo-cycled in a 96-Well GeneAmp ${ }^{\circledR}$ PCR System 9700 (Applied Biosystems). Purified products were electrophoresed on a SpectruMedix 9610 Aurora $^{\mathrm{TM}}$ DNA Sequencer (SpectruMedix LLC, State College, PA, USA) (Fig. 1).

Where biallelic analysis of specimens was undertaken, DNA templates amplified with fluorescent-labeled primers were processed in an ABI PRISM 3100 Genetic Analyzer (Applied Biosystem) for fluorescent quantification. The $(\mathrm{CAG})_{\mathrm{n}}$ was derived by subtracting a constant non-repetitive residue (in bp number) from the total number of bases of the synthesized amplicon in the exon 1 region of the AR gene for each X chromosome. The constant residue was measured by performing the analysis in a karyotypically normal man where the $(\mathrm{CAG})_{\mathrm{n}}$ was assessed by sequencing the AR gene motif and subtracting it from the total bp number obtained by quantification analysis.

Additional genetic studies. Chromosome analysis was performed on phytohemaglutinin (PHA)-stimulated peripheral blood lymphocytes with G-band staining. At least 20 metaphase cells were counted and a minimum of 5 cells was analyzed. In cases of complex structural chromosome aberrations, additional analysis by fluorescent in situ hybridization (FISH) was performed. All patients diagnosed with a chromosomal abnormality were offered genetic counseling.

To assess for $\mathrm{Y}$ chromosome microdeletions in the azoospermia factor (AZF) region, a total of 22 sequence tag sites (STSs) were analyzed by multiplex PCR and deletion breakpoints were defined with additional loci (16). Sperm cell aneuploidy screening was performed for chromosomes 18, 21, $\mathrm{X}$, and $\mathrm{Y}$ by FISH analysis $(4,5)$.

Data analysis. Statistical analysis was carried out by independent sample t-test to evaluate all mean comparison hypotheses. A logistic regression model was evaluated for fertility status as a function of CAG repeats. The odds ratio estimate associated with fertility status yielded a point estimate of 1.28 with $95 \%$ Wald confidence limits (1.051.57). For evaluation of the hypothesis of an increase in chromosomal abnormalities as sperm count decreases, a test 


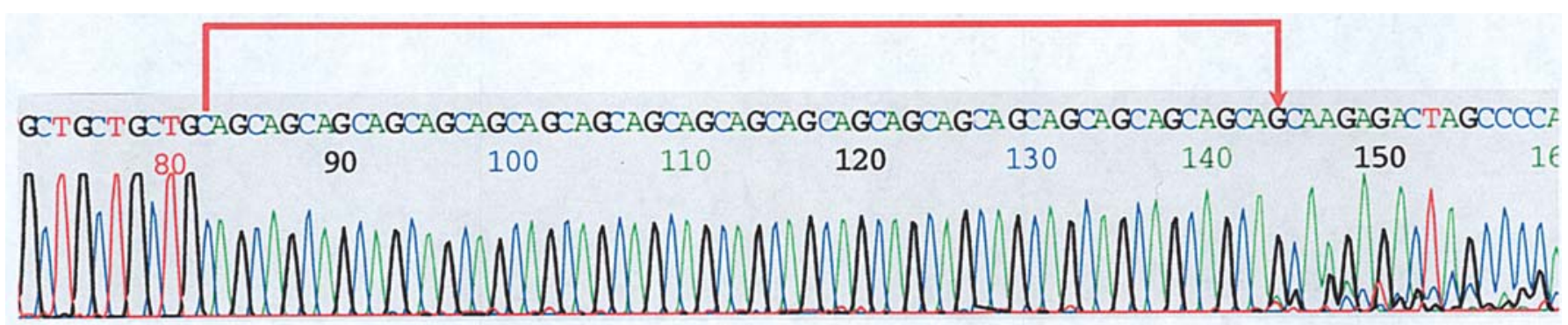

Figure 1. Gene sequencing of the $(\mathrm{CAG})_{\mathrm{n}}$ (glutamine sequence) androgen receptor gene with a polymorphic sequence of 21 repeat length. The CAA codon identifies the terminus of the polymorphic region.

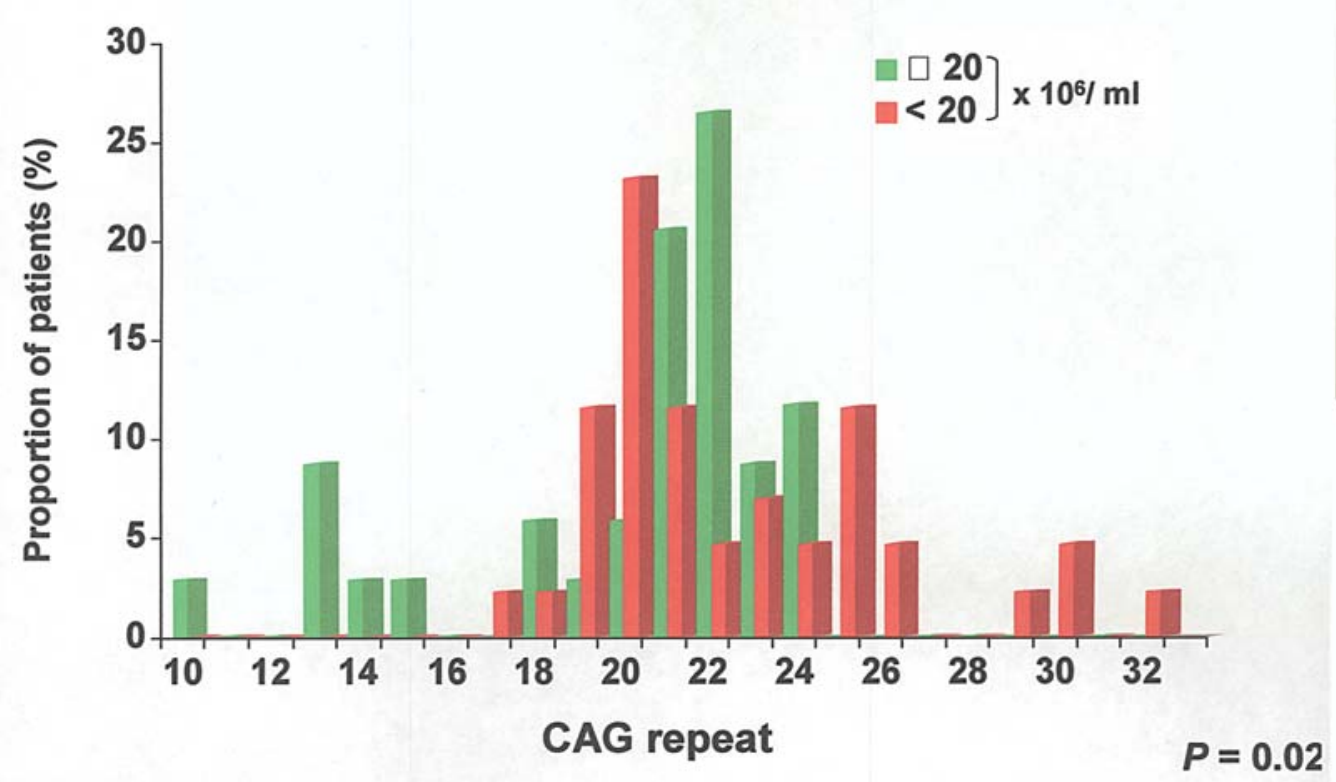

Figure 2. CAG repeat sizes within the AR gene of fertile and infertile men in relation to sperm concentration. The green bars represent percentages (\%) of men with normal sperm concentration $\left(\geq 20 \times 10^{6} / \mathrm{ml}\right)$, and red bars are used for oligozoospermic men $\left(<20 \times 10^{6} / \mathrm{ml}\right)$. CAG repeats $<17$ were consistently associated with a normal sperm concentration, while men with repeats $>25$ were all oligozoospermic.

Table I. Primer sequences used to synthesize exon 1 of the human androgen receptor gene.

\begin{tabular}{llcr}
\hline Analysis & & Sequence & Amplicon length (bp) \\
\hline \multirow{2}{*}{ Monoallelic } & F & 5'- TTC AGA ATC TGT TCC AGA GCG TGC -3' & 279 \\
& R & 5'- GCT GTG AAG GTT GCT GTT CCT CAT -3' & 279 \\
Biallelic & F & 5'- 6fam-TTC AGA ATC TGT TCC AGA GCG TGC -3' & \\
& R & 5'- GCT GTG AAG GTT GCT GTT CCT CAT -3' & \\
\hline
\end{tabular}

$\mathrm{F}$, forward; R, reverse.

of linear trend of proportions was conducted. Two-tailed tests were utilized and only $\mathrm{p}<0.05$ was considered significant. Statistical differences are reported in text and tables only when significant.

\section{Results}

Infertile males. Study subjects $(\mathrm{n}=77)$ provided one sample each and these were classified as azoospermic $(n=7)$, oligozoo- spermic $(n=43)$, asthenozoospermic $(n=40)$, and teratozoospermic $(n=59)$. Normozoospermic males of proven fertility $(n=13)$ served as controls. Mean $( \pm S D)$ age of infertile subjects and controls was $43.7 \pm 7$ and $44.8 \pm 7 \mathrm{yr}$, respectively. The average length of $(\mathrm{CAG})_{\mathrm{n}}$ repeats in the infertile men was significantly higher than the control group $(22.2 \pm 3$ vs. $19.3 \pm 5$; $\mathrm{p}=0.02$ by t-test). When logistic regression was performed using CAG repeats, the odds ratio for the fertility status was 1.28 (95\% CI: 1.05-1.57) ( $\mathrm{p}=0.01)$ (Table II). When the 
Table II. Observed CAG polymorphism lengths of ICSI and control (fertile) males.

\begin{tabular}{lcccc}
\hline & $n$ & $\begin{array}{c}\text { CAG repeats } \\
\text { (mean } \pm \text { SD }\end{array}$ & Range & $95 \%$ CI \\
\hline ICSI & 64 & $22.2 \pm 3^{\mathrm{a}}$ & $17-32$ & $21.5-22.9$ \\
Control & 13 & $19.3 \pm 5^{\mathrm{a}}$ & $10-24$ & $15.6-21.0$ \\
Total & 77 & $21.7 \pm 4$ & $10-32$ & $21.0-22.4$ \\
\hline
\end{tabular}

CI, confidence interval; ICSI, intracytoplasmic sperm injection; ${ }^{a}$ by Student's t-test (two independent samples), effect of $\mathrm{CAG}_{\mathrm{n}}$ polymorphism length on fertility status, $\mathrm{p}=0.02$.

Table III. The relationship between human androgen receptor CAG polymorphism lengths and sperm concentration.

\begin{tabular}{ccccc}
\hline Sperm concentration $\left(\times 10^{6} / \mathrm{ml}\right)$ & $n$ & CAG repeats & Range & $95 \%$ CI \\
\hline$<1$ & 13 & $23.1 \pm 4^{\mathrm{a}}$ & $19-32$ & $21.5-24.7$ \\
$1-<5$ & 14 & $22.8 \pm 4^{\mathrm{a}}$ & $17-30$ & $21.2-24.4$ \\
$5-<20$ & 16 & $21.6 \pm 2$ & $18-26$ & $20.7-22.6$ \\
$\geq 20$ & 34 & $20.6 \pm 3^{\mathrm{b}}$ & $10-25$ & $19.6-22.4$ \\
Total & 77 & $21.7 \pm 4$ & $10-32$ & $21.0-22.4$ \\
\hline
\end{tabular}

$\mathrm{CI}$, confidence interval; ${ }^{\mathrm{a}} \mathrm{vs}{ }^{\mathrm{b}}$, t-test using $\geq 20 \times 10^{6} / \mathrm{ml}$ concentration as reference: effect of sperm concentration on CAG polymorphism length, $\mathrm{p}<0.02$.

Table IV. The relationship between human androgen receptor CAG polymorphism lengths and sperm morphology.

\begin{tabular}{ccccr}
\hline \% normal morphology & $n$ & CAG repeats & Range & $95 \%$ CI \\
\hline$<1$ & 33 & $22.5 \pm 3^{\mathrm{a}}$ & $18-32$ & $21.5-23.5$ \\
$1-<4$ & 26 & $21.8 \pm 3$ & $17-30$ & $20.7-22.9$ \\
$\geq 4$ & 18 & $19.9 \pm 4^{\mathrm{b}}$ & $10-25$ & $18.1-21.7$ \\
Total & 77 & $21.7 \pm 4$ & $10-32$ & $21.0-22.4$
\end{tabular}

$\mathrm{CI}$, confidence interval; ${ }^{\mathrm{a}} \mathrm{vs}^{\mathrm{b}}{ }^{\mathrm{b}}$ Student's t-test (two independent samples): effect of sperm morphology on $\mathrm{CAG}_{\mathrm{n}}$ length, $\mathrm{p}<0.04$.

repeat lengths were ranked by semen characteristics, an inverse relationship was observed between the microsatellite sequence and sperm concentration and morphology $(\mathrm{p}=0.02$ and $\mathrm{p}=0.04$, respectively) (Tables III and IV), but not with sperm motility. Plotting the proportion of infertile individuals according to their repeat lengths versus sperm characteristics, a repeat length of less than $(\mathrm{CAG})_{17}$ was consistently associated with normal concentration (Fig. 2), motility, and morphology (Fig. 3). In contrast, microsatellite sequences over 25 in number correlated consistently with compromised concentration (Fig. 2) and morphology (Fig. 3), but not with sperm motility.

A normal peripheral karyotype was confirmed for all study subjects and controls. Yq deletion was identified in one patient $(1.3 \%)$ with an AZFc deletion. This subject also had the longest length of $(\mathrm{CAG})_{32}$. Chromosomal status was assessed by FISH analysis for 30 semen samples, revealing an overall incidence of chromosomal abnormalities of $1.5 \%$ (Table V). For all abnormality categories (autosomal, gonosomal, concurrent, and total), the linear trend was significant $(p<0.05)$. In all abnormality categories, the number of abnormalities significantly increased with a decrease in sperm concentration. The relationship between sperm concentration and percentage abnormalities was strongest in the autosomal and total. Although there was no correlation between the CAG length and the incidence of chromosomal abnormalities, the patient with $(\mathrm{CAG})_{32}$ and a Yq deletion also had a higher incidence $(2.9 \%)$ of chromosomal abnormalities in his spermatozoa, the concentration of which was 1,500 spermatozoa/ml. 
Table V. Fluorescent in situ hybridization analysis of sperm related to sperm concentration.

Classification of genetic abnormality $(\%)$

\begin{tabular}{crcrrrr}
\cline { 5 - 6 } Sperm concentration $\left(\mathrm{x} 10^{6} / \mathrm{ml}\right)$ & $n$ & Cells assessed & Autosomal $^{\mathrm{a}}$ & Gonosomal $^{\mathrm{a}}$ & Concurrent $^{\mathrm{a}}$ & Total $^{\mathrm{a}}$ \\
\hline$<1$ & 4 & 580 & $12(2.1)$ & $20(3.4)$ & $4(0.7)$ & $36(6.2)$ \\
$1-<5$ & 1 & 1,008 & $30(3.0)$ & $11(1.1)$ & $7(0.7)$ & $48(4.8)$ \\
$5-<20$ & 4 & 7,827 & $30(0.4)$ & $20(0.3)$ & $8(0.1)$ & $58(0.7)$ \\
$\geq 20$ & 21 & 59,049 & $323(0.5)$ & $329(0.6)$ & $209(0.3)$ & $861(1.5)$ \\
Total & 30 & 68,464 & $395(0.6)$ & $380(0.6)$ & $228(0.3)$ & $1,003(1.5)$
\end{tabular}

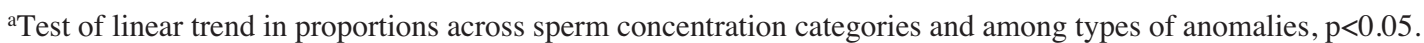

Table VI. CAG lengths of ICSI offspring with gonosomal abnormalities.

\begin{tabular}{ccc}
\hline Patient & Karyotype & CAG repeats \\
\hline 1 & $46, \mathrm{XY} / 47, \mathrm{XXY}$ & 21 \\
2 & $47, \mathrm{XXY}$ & $19 / 21$ \\
3 & $47, \mathrm{XYY}$ & 24 \\
\hline
\end{tabular}

ICSI male offspring. A genetic characterization was undertaken for 21 ICSI boys and 11 naturally conceived sons (controls). These children had an average age of $5 \pm 0.5 \mathrm{yr}$. The mean AR-CAG length among controls was $20.8 \pm 3.4$ and $21.4 \pm 3.2$ for the ICSI offspring (Table VI). Three boys conceived by ICSI had abnormal karyotypes: one a 47, XXY (complete Klinefelter) (Fig. 4A), another was a 46, XY/47, XXY (mosaic Klinefelter) (Fig. 4B), and a third 47, XYY. The complete Klinefelter case had (CAG) $)_{19 / 21}$, the mosaic Klinefelter case had a homozygous 21 repeat length, and the 47, XYY case had 24 repeats (Table VI). All three fathers of these children had normal karyotypes. The CAG repeat lengths of ICSI and spontaneously conceived children were within the expected range for a fertile population of a similar ethnic background (Table VII). No AZF deletions were identified in the ICSI or naturally conceived offspring.

\section{Discussion}

The integration of ICSI as a central component of the advanced reproductive technologies has attracted closer study of the genetics of male infertility. Such genetic abnormalities can manifest at a macrogenomic level (i.e., entire structural chromosomal aberrations) or be limited to microgenomic defects (i.e., Y chromosome microdeletions, $\mathrm{CF}$ mutations). Such genetic derangements support concern about the possibility of vertical transmission of genetic defects to the offspring.

A link between male infertility and expansion of the polymorphic trinucleotide (CAG) repeat in the AR gene has been demonstrated by several investigators $(13,19-24)$. In this study, we confirmed the inverse relationship between the polymorphic region of the AR gene and sperm production, specifically in regard to concentration and morphology. Our observations may appear to disagree with prior studies which failed to identify such a relationship (25-32) or at variance with work that focused on a single semen parameter (33). However, because the association between the AR gene and sperm production are ethnically variable, important trends may be difficult to identify in a heterogeneous population. When patients analyzed in the present study were stratified according to CAG lengths, the large majority of the AR polymorphic segments ranged between 18 and 24 repeats. Below $(\mathrm{CAG})_{17}$, semen production was preserved. Thus, trinucleotide repeats above $(\mathrm{CAG})_{26}$ indicate compromised concentration and morphology, though with only minor effects on motility.

Data from the present study corroborate findings of previous reports, where fertile males with short CAG repeat sequence had the highest sperm output (34), and subjects with $\geq 26$ AR-CAG repeats being at more than 4-fold increased risk for impaired spermatogenesis (35). We found males with an infertility problem were more likely than controls to have an expanded polymorphic region of the AR gene. Confirmation of the link between the expanded CAG sequence and spermatogenic defects in Caucasian men is parallel to similar studies in Asian, Indian, Australian, and North American populations $(20,27,36,37)$. Moreover, Eckardstein et al (38) reported Caucasian men with incomplete gonadotrophin suppression were 2.5 times more likely to be azoospermic when an expanded CAG sequence was present.

Instability of the AR-CAG sequence may arise via slipped mispairing at the replication fork, allowing an insertion when a newly synthesized strand dissociates from the primer strand during replication synthesis $(39,40)$. The new strand may then align with the repeat copy rather than its cognate copy. It has been observed that longer repeats are identifiable also in kidney cells kept in culture for several months (40), but in this study the $(\mathrm{CAG})_{\mathrm{n}}$ of ICSI sons was within the expected range, indicating that the in vitro process did not induce expansion of the trinucleotide sequence.

Although the AR gene (X chromosome) is not transmitted paternally to male offspring, it does directly pass to female offspring with a $95 \%$ chance of identical length (22). Thus 


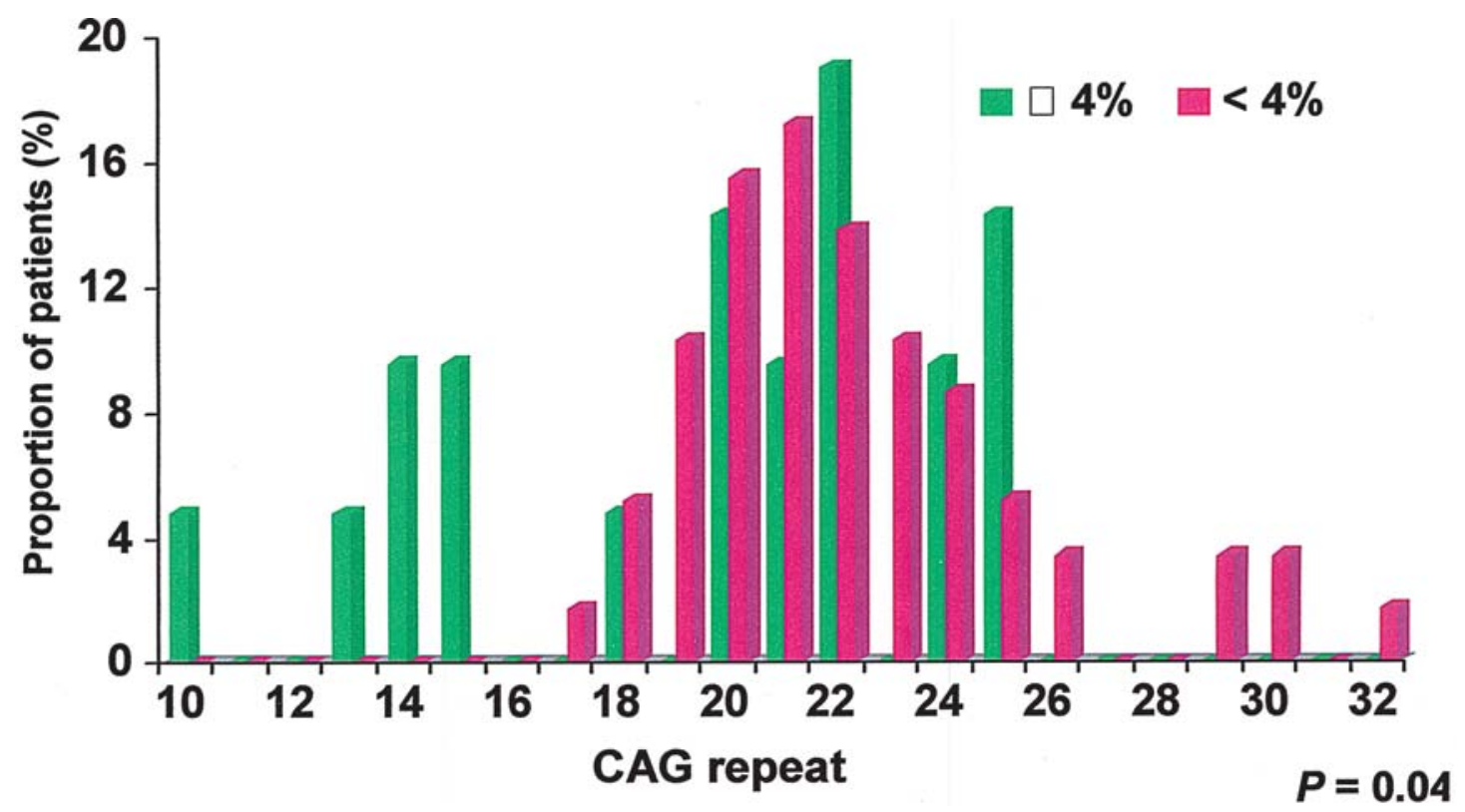

Figure 3. Distribution of CAG repeat sizes within the AR gene of fertile and infertile men, as a function of sperm morphology. The green bars represent percentages $(\%)$ of men with normal sperm morphology $(\geq 4 \%)$, and pink bars are used for teratozoospermic men $(<4 \%)$. CAGs repeats $<17$ predicted spermatozoa with normal morphology, and those $>26$ predicted some degree of teratozoospermia.

A

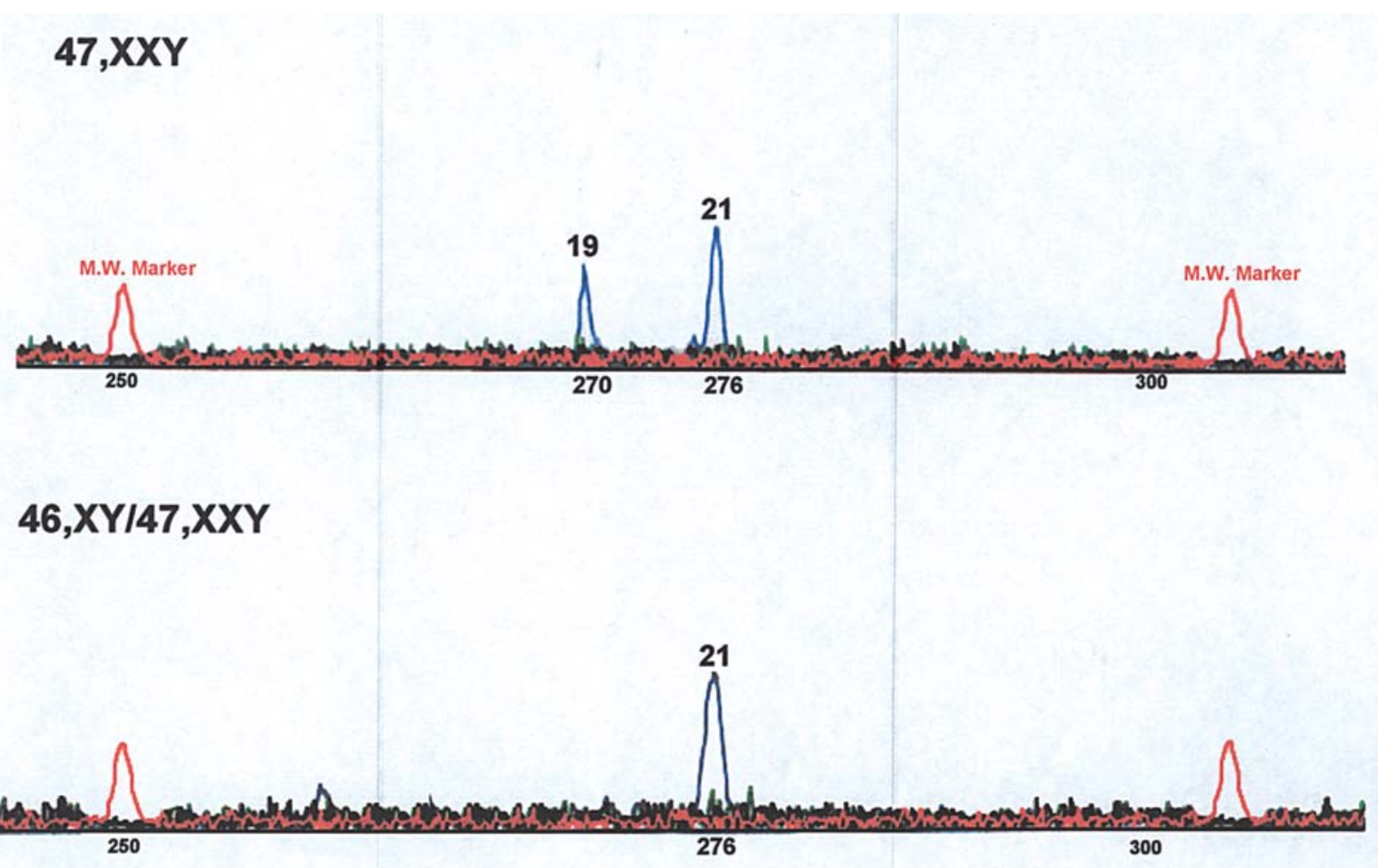

Figure 4. GeneMapper profiles of androgen receptor (AR) alleles from two ICSI boys. (A) Complete Klinefelter form with heterozygocity (2 signals, blue) and (B), mosaic Klinefelter with homozygous X chromosomes (1 signal, blue).

the latter would be carriers (first generation), with their male offspring (second generation) having an estimated $50 \%$ chance of inheriting the mutation of the polymorphic region. However, in such carrier daughters there is a 5\% risk that the CAG trinucleotide length may contract or expand by up to 8 unit base pairs, with consequent deleterious effects $(22,41)$. This would apply also in the case of male ICSI offspring.
In screening ICSI offspring fathered by men with genetically abnormal sperm, it is necessary to assess other genetic disorders that could contribute to impaired spermatogenesis. While no Yq deletions were detected in our population, de novo gonosomal abnormalities were observed in ICSI children and such abnormalities can have a direct impact on fertility (42). For example, Klinefelter syndrome is characterized by a 
Table VII. Comparison of CAG polymorphism lengths between ICSI offspring and naturally conceived boys.

\begin{tabular}{llccc}
\hline & $n$ & CAG repeats & Range & $95 \%$ CI \\
\hline ICSI & 21 & $21.4 \pm 3.2$ & $13-26$ & $20.0-22.8$ \\
Naturally conceived & 11 & $20.8 \pm 3.4$ & $13-25$ & $19.7-21.9$ \\
Total & 32 & $21.2 \pm 3.2$ & $13-26$ & $20.6-21.8$ \\
\hline
\end{tabular}

CI, confidence interval.

potentially compromised spermatogenesis $(43,44)$. However, the two Klinefelter children analyzed in our study both had a normal range of $(\mathrm{CAG})_{\mathrm{n}}$, suggesting spermatogenetic function may be conserved (45).

Knowledge of these genetic issues is essential for appropriate patient counseling and the development, where possible, of rational therapeutic plans. Outcome monitoring in the advanced reproductive technologies is critical, particularly regarding the future reproductive capacity of children conceived by ICSI (46-48). The present analysis suggests the application of ICSI has no bearing on the length of the polymorphic region of the AR gene in such male offspring.

Our findings also validate the concept that modulation of AR-CAG length directs spermatogenesis primarily as a secondary regulator of AR function. CAG repeats probably do not have a major independent effect on testis function, but rather may modify or fine-tune relevant endocrine feedback systems and hormone action. If this were not so, it would be expected that evolution selection pressure would cause such polymorphism to disappear from the reproductive pool (33). Thus, the overall fertility status of an individual would appear to depend not just on AR sequence alterations but also on interactions between other genomic and environmental factors. This multifactorial model implies that comparisons of reproductive potential based solely on sperm parameters may be insufficient to yield the complete picture, with consideration of the nuances the AR-CAG repeat yielding a more precise assessment.

Although the occurrence of de novo chromosomal abnormalities can be attributed to a mosaicism present in the sperm population of individuals with severe male infertility, a modification of the technique for biallelic analysis of the polymorphic region of exon 1 did allow measurement of the trinucleotide repeat length. It has been postulated that the AR-CAG is not linked to spermatogenesis in these individuals (45). However, mosaic or complete trisomic forms may be directly implicated in the compromised spermatogenesis (49), or, if maintained $(45,50)$, spermatozoa produced would have a disproportionately higher number of chromosomal aberrations $(5,51,52)$. This mosaic issue of the gamete population may nevertheless explain the origin of the de novo chromosomal abnormalities $(53,54)$ and tests to screen for this mosaicism are being developed (55). In our findings, chromosomal aneuploidy in spermatozoa of infertile men was inversely correlated with their concentration, and a trend toward a higher ratio of gonosomal defects was present in the most severe forms $\left(<1 \times 10^{6} / \mathrm{ml}\right)$. Finally, this observation tends to support the theory that genetically mosaic sperm occurs in higher frequency in infertile males. This finds confirmation in the reduced recombination frequency occurring together with other meiotic abnormalities observed in infertile men $(56,57)$. Our data show a positive correlation between the CAG repeat length and semen parameters, as the length of the ARCAG repeats seem to be negatively associated with spermatogenesis. Research is ongoing to develop better assessment of the AR as a way of screening sons of infertile men for eventual association with AR gene abnormalities, as a potential predictor of normal spermatogenesis prior to puberty.

\section{Acknowledgments}

We are indebted to the physicians and scientists of the Center for Reproductive Medicine and Infertility, Weill Medical College of Cornell University with particular gratitude to the reproductive endocrinologists and urologists. We are most grateful to Professor J. Michael Bedford for his critical reading of the manuscript, Alfred Wang for data compilation, and Maryanne Williams Pitman for recruiting patients. The data were presented in part at the 59th Annual Meeting of the American Society for Reproductive Medicine, San Antonio, TX, USA, October 2003.

\section{References}

1. Baker HW: Male infertility. Endocrinol Metab Clin North Am 23: 783-793, 1994.

2. de Kretser DM: Male infertility. Lancet 349: 787-790, 1997.

3. Chandley AC: The chromosomal basis of human infertility. $\mathrm{Br}$ Med Bull 35: 181-186, 1979.

4. Colombero LT, Hariprashad JJ, Tsai MC, Rosenwaks Z and Palermo GD: Incidence of sperm aneuploidy in relation to semen characteristics and assisted reproductive outcome. Fertil Steril 72: 90-96, 1999.

5. Palermo GD, Colombero LT, Hariprashad JJ, Schlegel PN and Rosenwaks Z: Chromosome analysis of epididymal, and testicular sperm in azoospermic patients undergoing ICSI. Hum Reprod 17: 570-575, 2002.

6. Schlegel PN, Cohen J, Goldstein M, Alikani M, Adler A, Gilbert BR, et al: Cystic fibrosis gene mutations do not affect sperm function during in vitro fertilization with micromanipulation for men with bilateral congenital absence of vas deferens. Fertil Steril 64: 421-426, 1995.

7. Cruger DG, Agerholm I, Byriel L, Fedder J, Bruun-Petersen G: Genetic analysis of males from intracytoplasmic sperm injection couples. Clin Genet 64: 198-203, 2003.

8. Lubahn DB, Joseph DR, Sar M, Tan J, Higgs HN, Larson RE, et al: The human androgen receptor: complementary deoxyribonucleic acid cloning, sequence analysis and gene expression in prostate. Mol Endocrinol 2: 1265-1275, 1988.

9. Sills ES, Sholes TE, Perloe M, Kaplan CR, Davis JG and Tucker MJ: Characterization of a novel receptor mutation $\mathrm{A} \rightarrow \mathrm{T}$ at exon 4 in complete androgen insensitivity syndrome and a carrier sibling via bidirectional polymorphism sequence analysis. Int J Mol Med 9: 45-48, 2002. 
10. MacLean HE, Warne GL and Zajac JD: Defects of androgen receptor function: from sex reversal to motor neuron disease. Mol Cell Endocrinol 112: 133-141, 1995.

11. La Spada AR, Wilson EM, Lubahn DB, Harding AE and Fischbeck KH: Androgen receptor gene mutations in X-linked spinal bulbar muscular atrophy. Nature 352: 77-79, 1991.

12. Andrew SE, Goldberg YP, Hayden MR: Rethinking genotype and phenotype correlations in polygluyamine expansion disorders. Hum Mol Genet 6: 2005-2010, 1997.

13. Mifsud A, Sim CK, Boettger-Tong H, Moreira S, Lamb DJ, Lipshultz LL, et al: Trinucleotide (CAG) repeat polymorphisms in the androgen receptor gene: molecular markers of risk for male infertility. Fertil Steril 75: 275-281, 2001.

14. Casella R, Maduro MR, Misfud A, Lipshultz LI, Yong EL and Lamb DJ: Androgenreceptor gene polyglutamine length is associated with testicular histology in infertile patients. J Urol 169: 224-227, 2003.

15. Edwards A, Hammond HA, Jin L, Caskey CT and Chakraborty R: Genetic variation at five trimeric and tetrameric tandem repeat loci in four human population groups. Genomics 12: 241-253, 1992.

16. Katagiri Y, Neri QV, Takeuchi T, Schlegel PN, Megid WA, Kent-First M, et al: Y chromosome assessment and its implication for the development of ICSI children. Reprod Biomed Online 8: 307-318, 2004.

17. Marcelli M, Tilley WD, Wilson CM, Griffin JE, Wilson JD and McPhaul MJ: Definition of human androgen receptor gene structure permits the identification of mutations that cause androgen resistance: Premature termination of the receptor protein at amnio acid residue 588 causes complete androgen resistance. Mol Endocrinol 4: 1105-1116, 1990.

18. Bharaj BS, Vassilikos EJK and Diamandis EP: Rapid and accurate determination of $(\mathrm{CAG})_{\mathrm{n}}$ repeats in the androgen receptor gene using polymerase chain reaction and automated fragment analysis. Clin Biochem 32: 327-332, 1999.

19. Dowsing AT, Yong EL, Clark M, McLachlan RI, de Kretser DM and Trounson AO: Linkage between male infertility and trinucleotide expansion in the androgen receptor gene. Lancet 354: 640-643, 1999.

20. Komori S, Kasumi H, Kanazawa R, Sakata K, Nakata Y, Kato H, et al: CAG repeat length in the androgen receptor gene of infertile Japanese males with oligozoospermia. Mol Hum Reprod 5: 14-16, 1999.

21. Yoshida KI, Yano M, Chiba K, Honda M and Kitahara S: CAG repeat length in the androgen receptor gene is enhanced in patients with idiopathic azoospermia. Urology 54: 1078-1081, 1999.

22. Patrizio P, Leonard DG, Chen KL, Hernandez-Ayup S and Trounson AO: Larger trinucleotide repeat size in the androgen receptor gene of infertile men with extremely severe oligozoospermia. J Androl 22: 444-448, 2001

23. Wallerand $\mathrm{H}$, Chabannes $\mathrm{E}$ and Bittard $\mathrm{H}$ : Idiopathic male infertility and androgen receptors. Prog Urol 11: 610-620, 2001.

24. Kukuvitis A, Georgiou I, Bouba I, Tsirka A, Giannouli CH, Yapijakis $\mathrm{C}$, et al: Association of oestrogen receptor alpha polymorphisms and androgen receptor CAG trinucleotide repeats with male infertility: a study in 109 Greek infertile men. Int J Androl 25: 149-152, 2002.

25. Giwercman YL, Xu C, Arver S, Pousette A and Reneland R: No association between the androgen receptor gene CAG repeat and impaired sperm production in Swedish men. Clin Genet 54: 435-436, 1998.

26. Dadze S, Wieland C, Jakubiczka S, Funke K, Schroder E, Rover-Pokora B, et al: The size of the CAG repeat in exon 1 of the androgen receptor gene shows no significant relationship to impaired spermatogenesis in an infertile Caucasoid sample of German origin. Mol Hum Reprod 6: 207-214, 2000.

27. Loy CJ and Yong EL: Sex, infertility and the molecular biology of the androgen receptor. Curr Opin Obstet Gynecol 13: 315-321, 2001.

28. Sasagawa I, Suzuki Y, Ashida J, Nakada T, Muroya K and Ogata T: CAG repeat length analysis and mutation screening of the androgen receptor gene in Japanese men with idiopathic azoospermia. J Androl 22: 804-808, 2001.

29. Van Golde R, Van Houwelingen K, Kiemeney L, Kremer J, Tuerlings J, Schalken J, et al: Is increased CAG repeat length in the androgen receptor gene a risk factor for male subfertility? J Urol 67: 621-623, 2002.

30. Rajpert-De Meyts E, Leffers H, Petersen JH, Andersen AG, Carlsen E, Jorgensen $\mathrm{N}$, et al: CAG repeat length in androgenreceptor gene and reproductive variables in fertile and infertile men. Lancet 359: 44-46, 2002.
31. Erasmuson T, Sin IL and Sin FY: Absence of association of androgen receptor trinucleotide expansion and poor semen quality. Int J Androl 26: 46-51, 2003.

32. Lund A, Tapanainen JS, Lahdetie J, Savontaus ML and Aittomaki K: Long CAG repeats in the AR gene are not associated with infertility in Finnish males. Acta Obstet Gynecol Scand 82: 162-166, 2003.

33. Milatiner D, Halle D, Huerta M, Margalioth EJ, Cohen Y, Ben-Chetrit A, et al: Associations between androgen receptor CAG repeat length and sperm morphology. Hum Reprod 19: 1426-1430, 2004.

34. Eckardstein SV, Syska A, Gromoll J, Kamischke A, Simoni M and Nieschlag E: Inverse correlation between sperm concentration and number of androgen receptor CAG repeats in normal men. $\mathrm{J}$ Clin Endocrinol Metab 86: 2585-2590, 2001.

35. Mengual L, Oriola J, Ascaso C, Ballesca JL and Oliva R: An increased $\mathrm{CAG}$ repeat length in the androgen receptor gene in azoospermic ICSI candidates. J Androl 24: 279-284, 2003.

36. Tut TG, Ghadessy FJ, Trifiro MA, Pinsky L and Yong EL: Long polyglutamine tracts in the androgen receptor are associated with reduced trans-activation, impaired sperm production, and male infertility. J Clin Endocr Metab 82: 3777-3782, 1997.

37. Tse JY, Liu VW, Yeung WS, Lau EY, Ng EH and Ho PC: Molecular analysis of the androgen receptor gene in Hong Kong Chinese infertile men. J Assist Reprod Genet 20: 227-233, 2003.

38. Eckardstein SV, Schmidt A, Kamischke A, Simoni M, Gromoll J, Nieschlag E: CAG repeat length in the androgen receptor gene and gonadotrophin suppression influence the effectiveness of hormonal male contraception. Clin Endocrinol 57: 647-655, 2002.

39. Pearson CE and Sinden RR: Alternative structures in duplex DNA formed within the trinucleotide repeats of the myotonic dystrophy and fragile X loci. Biochemistry 35: 41-53, 1996.

40. Gomes-Pereira M, Fortune MT and Monckton DG: Mouse tissue culture models of unstable triplet repeats in vitro selection for larger alleles, mutational expansion bias and tissue specificity, but no association with cell division rates. Hum Mol Genet 10: 845-854, 2001.

41. Cram DS, Song B, McLachlan RI and Trounson AO: CAG trinucleotide repeats in the androgen receptor gene of infertile men exhibit stable inheritance in female offspring conceived after ICSI. Mol Hum Reprod 6: 861-866, 2000.

42. Mau UA, Backert IT, Kaiser P and Kiesel L: Chromosomal findings in 150 couples referred for genetic counselling prior to intracytoplasmic sperm injection. Hum Reprod 12: 930-937, 1997.

43. Paulsen CA, Gordon DL, Carpenter RW, Gandy HM and Drucker WD: Klinefelter's syndrome and its variants: a hormonal and chromosomal study. Recent Prog Horm Res 24: 321-363, 1968.

44. Luciani JM, Mattei A, Devictor-Vuillet M, Rubin, Stahl A and Vague J: Study of meiotic chromosomes in a case of Klinefelter's disease with spermatogenesis and 46, XY-47, XXY karyotypes. Ann Genet 13: 249-253, 1970.

45. Suzuki Y, Sasagawa I, Tateno T, Ashida J, Nakada T, Muroya K, et al: Mutation screening and CAG repeat length analysis of the androgen receptor gene in Klinefelter's syndrome patients with and without spermatogenesis. Hum Reprod 16: 1653-1656, 2001.

46. Bowen JR, Gibson FL, Leslie GI and Saunders DM: Medical and developmental outcome at 1 year for children conceived by intracytoplasmic sperm injection. Lancet 351: 1529-1534, 1998

47. Bonduelle M, Joris H, Hofmans K, Liebaers I and Van Steirteghem A: Mental development of 201 ICSI children at 2 years of age. Lancet 351: 1553, 1998.

48. Palermo GD, Takeuchi T, Neri QV, Katagiri Y, Veeck LL and Rosenwaks Z: Application of intracytoplasmic sperm injection in assisted reproductive technologies. Reprod Biomed Online 6: 456-463, 2003.

49. Smyth CM and Bremner WJ: Klinefelter syndrome. Arch Intern Med 158: 1309-1314, 1998.

50. Harari O, Bourne H, Baker G, Gronow M and Johnston I: High fertilization rate with intracytoplasmic sperm injection in mosaic Klinefelter's syndrome. Fertil Steril 63: 182-184, 1995.

51. Bonduelle M, Camus M, De Vos A, Staessen C, Tournaye H, Van Assche E, et al: Seven years of intracytoplasmic sperm injection and follow-up of 1987 subsequent children. Hum Reprod Suppl 1: 243-264, 1999. 
52. Devroey P and Van Steirteghem A: A review of ten years experience of ICSI. Hum Reprod Update 10: 19-28, 2004.

53. Mroz K, Hassold TJ and Hunt PA: Meiotic aneuploidy in the XXY mouse: evidence that a compromised testicular environment increases the incidence of meiotic errors. Hum Reprod 14: 1151-1156, 1999.

54. Blanco J, Egozcue J and Vidal F: Meiotic behaviour of the sex chromosomes in three patients with sex chromosome anomalies (47, XXY, mosaic 46, XY/47, XXY and 47, XYY) assessed by fluorescence in-situ hybridization. Hum Reprod 16: 887-892, 2001.
55. Paduch DA, Mielnik A and Schlegel PN: Novel mutations in testis-specific ubiquitin protease 26 gene may cause male infertility and hypogonadism. Reprod Biomed Online 10: 747-754, 2005.

56. Sun F, Kozak G, Scott S, Trpkov K, Ko E, Mikhaail-Philips M, et al: Meiotic defects in a man with non-obstructive azoospermia: Case report. Hum Reprod 19: 1770-1773, 2004.

57. Gonsalves J, Sun F and Schlegel PN: Defective recombination in infertile men. Hum Mol Genet 13: 2875-2883, 2004. 